\title{
Relationship between newborn craniotabes and vitamin D status
}

\author{
Makbule Ercan, ${ }^{1}$ Mustafa Ozcetin, ${ }^{2}$ Mehmet Karaci, ${ }^{3}$ Gamze Ozgurhan, ${ }^{2}$ \\ Adem Yasar, ${ }^{3}$ Berrak Guven ${ }^{4}$ \\ ${ }^{1}$ Faculty of Medicine, Department of Pediatrics, Bulent Ecevit University, Zonguldak, Turkey \\ ${ }^{2}$ Children's Health and Diseases Clinic, Dr. Lutfi Kirdar Kartal Training and Research Hospital, Istanbul, Turkey \\ ${ }^{3}$ Children's Health and Diseases Clinic, Fatih Sultan Mehmet Training and Research Hospital, Istanbul, Turkey \\ ${ }^{4}$ Faculty of Medicine, Department of Biochemistry, Bulent Ecevit University, Zonguldak, Turkey
}

\begin{abstract}
OBJECTIVE: In recent studies, vitamin $D$ deficiency during pregnancy and early infancy has been reported to predispose children to many chronic diseases, except those of the skeletal system. The aim of this study was to investigate whether craniotabes in otherwise healthy newborns is physiological, its relationship to vitamin $D$ deficiency and whether or not it requires treatment.

METHODS: A total of 150 healthy newborns with a weight of over $2000 \mathrm{~g}$ were included. Newborns were divided into two groups during postnatal discharge (1-3.'s day): those with and without craniotabes. The 25-hydroxy $(\mathrm{OH})$ vitamin $D$ levels of the newborns' mothers were measured, and all infants were re-evaluated for craniotabes, as well as tested to determine levels of serum calcium (Ca), phosphorus (P), alkaline phosphatase (ALP), parathyroid hormone $(\mathrm{PTH})$ and $25(\mathrm{OH})$ vitamin $\mathrm{D}$, urine calcium and creatinine.

RESULTS: Craniotabes was present in $45(30 \%)$ of newborns enrolled in the study. Craniotabes of the newborns born during the winter months was significantly higher. PTH level was significantly higher in 1-month-old newborns with craniotabes than those without craniotabes. No relationship was observed between diet and craniotabes, but in exclusively breastfed infants, vitamin D level was statistically significantly lower. No statistically significant difference was found in the occurrence of craniotabes in newborns with or without vitamin $D$ support.

CONCLUSION: The relationship between newborn craniotabes and maternal vitamin $D$ deficiency is not clear. However, the present study illustrates that maternal vitamin D deficiency is still a major problem. Therefore, measures to prevent maternal vitamin $D$ deficiency should be strengthened.
\end{abstract}

Keywords: Craniotabes; newborn; vitamin D deficiency.

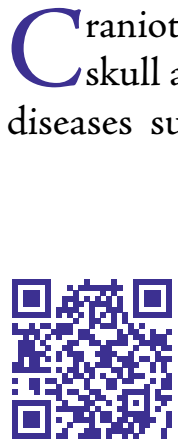

Received: December 14, 2015 Accepted: February 05, 2016 Online: May 02, 2016 
tion that does not require treatment. It is found in up to $30 \%$ of healthy neonates, and usually heals within 2-3 months $[1,2]$. Craniotabes is thought to be due to minor changes in calcium metabolism and the physiological compaction of premature engagement of the head [1].

Unlike classical vitamins, vitamin D is synthesized in the body and termed a hormone. In recent studies, vitamin D deficiency during pregnancy and early infancy has been reported to predispose children to many chronic diseases, except those of skeletal system [3, 4]. For this reason, requiring normal vitamin $\mathrm{D}$ values has gained more importance $[5$, 6]. In studies conducted in Turkey, maternal vitamin $\mathrm{D}$ deficiency is reported to be $80 \%$ [7].

Intrauterine exposure to temporary vitamin $\mathrm{D}$ deficiency during infancy or childhood creates an increased risk for type 1 diabetes mellitus, asthma, lower respiratory tract infections and even schizophrenia [4, 8-10]. If craniotabes in normal neonates reflects vitamin $\mathrm{D}$ deficiency in utero, and if the condition persists in infancy, it may lead to a variety of health problems later in life. Accordingly, treatment with vitamin $\mathrm{D}$ would be appropriate in those newborns [11]. The aim of this study was to investigate whether craniotabes in otherwise healthy newborns is physiological, its relationship to vitamin D deficiency and whether or not it requires treatment.

\section{MATERIALS AND METHODS}

The study consisted of 150 neonates born at term between April 2012 and April 2013 in Bulent Ecevit University Medical Faculty Hospital and was conducted prospectively. It included 150 healthy, term infants with a body weight of more than 2000 g. No sex discrimination was made. Infants whose families declined to sign a written consent agreement, and those with acute illness, major congenital anomalies, abnormal calcium metabolism or liver disease were excluded.

Newborns included in the study were examined by one physician for craniotabes (first and third day) on discharge and divided into two groups: those with craniotabes (study group) and without craniotabes (control group). Presence of soft bones, inward collapse when pressure was applied to parieto-occipital region with the index and middle fingers of both hands and typically snapping back when pressure was relieved was considered to constitute craniotabes.

Serum 25-hydroxy $(\mathrm{OH})$ vitamin D levels were measured in all mothers of participating infants. The same physician repeated the physical examination of all the newborns when they were 1 month old to evaluate the presence of craniotabes and levels of serum calcium $(\mathrm{Ca})$, phosphorus $(\mathrm{P})$, alkaline phosphatase (ALP), parathyroid hormone (PTH), $25(\mathrm{OH})$ vitamin $\mathrm{D}$, urinary calcium and creatinine.

Epidemiological data was gathered, including, date of birth; birth weight; gestational week; gender; maternal age; number of pregnancies; number of children; mother's education level; mother's occupation; mother's clothing style; daily, weekly and monthly average duration of exposure to the sun; cigarette usage; place of residence (rural/urban), calcium and vitamin $\mathrm{D}$ supplementation during pregnancy; nutritional status of baby up to 1 month of age; vitamin $\mathrm{D}$ supplementation in infancy and if provided, date initiated. Infants who were breastfed but received more than $40 \mathrm{~mL}$ per day formula were considered to be mixed-fed. The information obtained was examined for relationship to craniotabes.

The study was approved by the Ethics Committee of Bulent Ecevit University School of Medicine and written informed consent was obtained from parents.

Data were evaluated using SPSS software (version 13.0; SPSS Inc, Chicago, IL, USA). Numerical variables were presented as mean, standard deviation, median, minimum and maximum values; categorical variables were shown with frequencies and percentages. All comparisons in statistical analysis with $\mathrm{p}$-value of $<0.05$ were considered statistically significant.

\section{RESULTS}

The study included 150 neonates born at term between April 2012 - April 2013 in Bulent Ecevit 
TABLE1. Gestational ages, birth seasons, birth weights of newborns

\begin{tabular}{lcccc} 
& & & \multicolumn{2}{c}{ Season } \\
\cline { 3 - 4 } Craniotabes $(\mathrm{n})$ & Gestational Age (days) & Birth Weight $(\mathrm{g})$ & Summer $\mathrm{n}(\%)$ & Winter $\mathrm{n}(\%)$ \\
\hline With (45) & $268.87 \pm 7.51$ & $3027.44 \pm 486.11$ & $0(0)$ & $45(45,9)$ \\
Without (105) & $271.43 \pm 8.21$ & $(2100-3940)$ & $46(100)$ & $53(54,1)$ \\
$\mathrm{p}$ & 0.091 & $(2400-4740)$ & & \\
& & $0.002^{*}$ & $<0,001^{*}$
\end{tabular}

University Medical Faculty Hospital. Of the total, 79 were female $(52.6 \%)$ and 71 were male $(47.4 \%)$. Craniotabes was detected in 45 (30\%) of the newborns enrolled in the study and the sex ratio of participants with and without craniotabes was similar.

Neonates with and without craniotabes were compared in terms of gestational age and birth weight. No statistically significant relationship was detected between craniotabes and weeks of gestation, but in newborns with low birth weight, the incidence of craniotabes was found to be significantly higher $(p=0.002)$. All of the patients with cranio- tabes were born in the fall and winter months with poor sunlight (Table 1). The incidence of craniotabes was significantly higher in infants born during the winter months $(p<0.001)$.

There was no statistically significant relationship between education, profession, the family residence, clothing styles and craniotabes (Table 2). Mothers' use of cigarettes did not increase the incidence of craniotabes statistically, but detection of craniotabes in $50 \%$ of infants whose mothers smoke and only in $27.9 \%$ of infants of non-smoking mothers suggests that smoking may increase the risk of craniotabes.

TABLE 2. Relationship between craniotabes and some perinatal maternal factors

\begin{tabular}{|c|c|c|c|c|c|c|c|}
\hline \multirow[t]{2}{*}{ Mother's } & & \multicolumn{2}{|c|}{ With Craniotabes } & \multicolumn{2}{|c|}{ Without Craniotabes } & \multirow[b]{2}{*}{ Total } & \multirow[b]{2}{*}{$\mathrm{p}$} \\
\hline & & $\mathrm{n}$ & $\%$ & $\mathrm{n}$ & $\%$ & & \\
\hline \multirow{4}{*}{ Education } & Primary school & 26 & 27.1 & 70 & 72.9 & 96 & \\
\hline & High school & 13 & 37.1 & 22 & 62.9 & 35 & 0.539 \\
\hline & University & 6 & 31.6 & 13 & 68.4 & 19 & \\
\hline & Housewife & 35 & 28.9 & 86 & 71.1 & 121 & \\
\hline \multirow[t]{2}{*}{ Profession } & Worker & 5 & 38.5 & 8 & 61.5 & 13 & 0.778 \\
\hline & Officer & 5 & 31.3 & 11 & 68.8 & 16 & \\
\hline \multirow[t]{2}{*}{ Clothes } & Modern & 17 & 30.9 & 38 & 69.1 & 55 & 0.351 \\
\hline & Traditional & 28 & 29.5 & 67 & 70.5 & 95 & \\
\hline \multirow[t]{2}{*}{ Family residence } & Urban & 32 & 30.5 & 73 & 69.5 & 105 & 0.254 \\
\hline & Rural & 13 & 28.9 & 32 & 71.1 & 45 & \\
\hline \multirow[t]{2}{*}{ Smoking status } & Smoker & 7 & 50 & 7 & 50 & 14 & 0.123 \\
\hline & Non-smoker & 38 & 27.9 & 98 & 72.1 & 136 & \\
\hline
\end{tabular}


TABLE 3. 25-hydroxy (OH) vitamin D level and duration of calcium (Ca)-vitamin D intake of mother

\begin{tabular}{lcc} 
Craniotabes & $\begin{array}{c}\text { Duration of Ca-Vit D } \\
\text { suplementation of mother (months) }\end{array}$ & $\begin{array}{c}25(\mathrm{OH}) \text { vitamin D level of } \\
\text { mother }(\mathrm{ng} / \mathrm{mL})\end{array}$ \\
\hline With & $4.52 \pm 2.15(1-9)$ & $22.7 \pm 6.8(4.9-36.3)$ \\
Without & $4.35 \pm 1.8(1-9)$ & $22 \pm 5.9(8.2-35.9)$ \\
$P$ & 0.843 & 0.410
\end{tabular}

Mothers were evaluated in terms of receiving calcium and vitamin $\mathrm{D}$ supplementation during pregnancy. Groups were defined as receiving either calcium or vitamin $\mathrm{D}$, receiving both, and receiving neither in terms of likelihood of craniotabes; no statistically significant difference was detected between the groups. Additionally, craniotabes incidence and calcium and vitamin $\mathrm{D}$ supplementation period of mothers and maternal $25(\mathrm{OH})$ vitamin D levels were compared. There was no statistically significant difference (Table 3). However, serum $25(\mathrm{OH})$ vitamin D levels $<10 \mathrm{ng} / \mathrm{mL}$ were detected in $6.6 \%$ of mothers of neonates with craniotabes, while serum $25(\mathrm{OH})$ vitamin D levels $<10 \mathrm{ng} / \mathrm{mL}$ were detected in $0.95 \%$ of mothers of neonates without craniotabes. Vitamin D deficiency was observed in $96 \%$ of mothers while $90 \%$ of neonates had normal (>20ng/ml) vitamin D levels. No statistically significant relationship was detected between craniotabes and daily, weekly and monthly sunshine exposure.

All neonates were examined at the newborn clinic at 1 month of age. Of 45 newborns that initially had craniotabes $(68.8 \%)$, it was still present in 31 at 1 month of age. No statistically significant relationship was found between gender and persistent craniotabes. Although no significant difference was observed between gestational age and persistent craniotabes, more low birth weight newborns had craniotabes than newborns with normal birth weight. Those with craniotabes had $2899.5 \pm 448.3$ g average birth weight, while the average birth weight was $3316.6 \pm 458.2 \mathrm{~g}$ for newborns without craniotabes $(\mathrm{p}<0.001)$.

Mothers who received calcium and vitamin D supplementation and those who did not were compared, and there was no statistically significant difference between the two groups in terms of average maternal $25(\mathrm{OH})$ vitamin $\mathrm{D}$ level and serum $\mathrm{Ca}$,

TABLE 4. Relationship between craniotabes seen soon after birth and $\mathrm{Ca}, \mathrm{P}, \mathrm{ALP}, \mathrm{PTH}, 25(\mathrm{OH})$ vitamin $\mathrm{D}$, urine $\mathrm{Ca} /$ creatinine levels of newborns

\begin{tabular}{lcccccc} 
& \multicolumn{5}{c}{ Newborns at 1 month } \\
\cline { 2 - 7 } Craniotabes & $\begin{array}{c}\text { Serum Ca } \\
\mathrm{mg} / \mathrm{dL}\end{array}$ & $\begin{array}{c}\text { Serum P } \\
\mathrm{mg} / \mathrm{dL}\end{array}$ & $\begin{array}{c}\mathrm{ALP} \\
\mathrm{U} / \mathrm{L}\end{array}$ & $\begin{array}{c}\mathrm{PTH} \\
\mathrm{pg} / \mathrm{mL}\end{array}$ & $\begin{array}{c}25(\mathrm{OH}) \text { vitamin D } \\
\mathrm{ng} / \mathrm{mL}\end{array}$ & UrineCa/Cr \\
\hline With & $10.40 \pm 0.42$ & $6.60 \pm 0.56$ & $312.8 \pm 64.5$ & $39.8 \pm 21.9$ & $31.7 \pm 12.5$ & $0.61 \pm 0.42$ \\
& $(9.6-11.5)$ & $(5-7.4)$ & $(156-466)$ & $(3-92)$ & $(11.6-83)$ & $(0.1-1.82)$ \\
Without & $10.5 \pm 0.35$ & $6.50 \pm 0.54$ & $337.2 \pm 109$ & $32.6 \pm 17.9$ & $30.2 \pm 8.5$ & $0.58 \pm 0.33$ \\
& $(9.8-11.4)$ & $(4.6-7.7)$ & $(140-712)$ & $(3-100)$ & $(10.5-65.5)$ & $(0.04-2.23)$ \\
$\mathrm{p}$ & 0.053 & 0.176 & 0.387 & $0.03 *$ & 0.499 & 0.972
\end{tabular}

Ca: calcium; P: phosphorus; ALP: alkaline phosphatase; PTH: parathyroid hormone; OH: hydroxy. 
P, ALP, PTH, $25(\mathrm{OH})$ vitamin $\mathrm{D}$, and urine calci$\mathrm{um} /$ creatinine levels of newborns at 1 month of age. Newborns who had craniotabes and were exclusively breastfed had significantly higher serum PTH levels than those without craniotabes $(p=0.03)$. Between the two groups, there was no significant correlation in terms of $25(\mathrm{OH})$ vitamin D levels of mothers and newborns (Table 4).

Of the 150 newborns in the study, 86 (57.3\%) were breastfed, $4(2.7 \%)$ were formula-fed and 60 $(40 \%)$ were both breastfed and formula-fed. When the relationship between feeding patterns and craniotabes persisting at 1 month of age was evaluated, no statistically significant difference was found.

Infants who were exclusively breastfed had an average of $27.5 \pm 7.5 \mathrm{ng} / \mathrm{mL} 25(\mathrm{OH})$ vitamin D level, whereas formula and mixed-fed infants had an average of $34.8 \pm 10.9 \mathrm{ng} / \mathrm{ml} 25(\mathrm{OH})$ vitamin D level $(p<0.0001$, Figure 1). Four newborns $(2.7 \%)$ had vitamin $\mathrm{D}$ deficiency $(<15 \mathrm{ng} / \mathrm{mL}), 11(7.3 \%)$ had vitamin D insufficiency $(15-20 \mathrm{ng} / \mathrm{mL})$, and 135 $(90 \%)$ of all newborns had vitamin D levels within normal limits (>20 ng/ml). According to maternal vitamin D levels, 103 of 150 mothers $(68.7 \%)$ had vitamin D deficiency $(<25 \mathrm{ng} / \mathrm{mL}), 41$ of them (27.3\%) had vitamin D insufficiency $(25-32 \mathrm{ng} /$

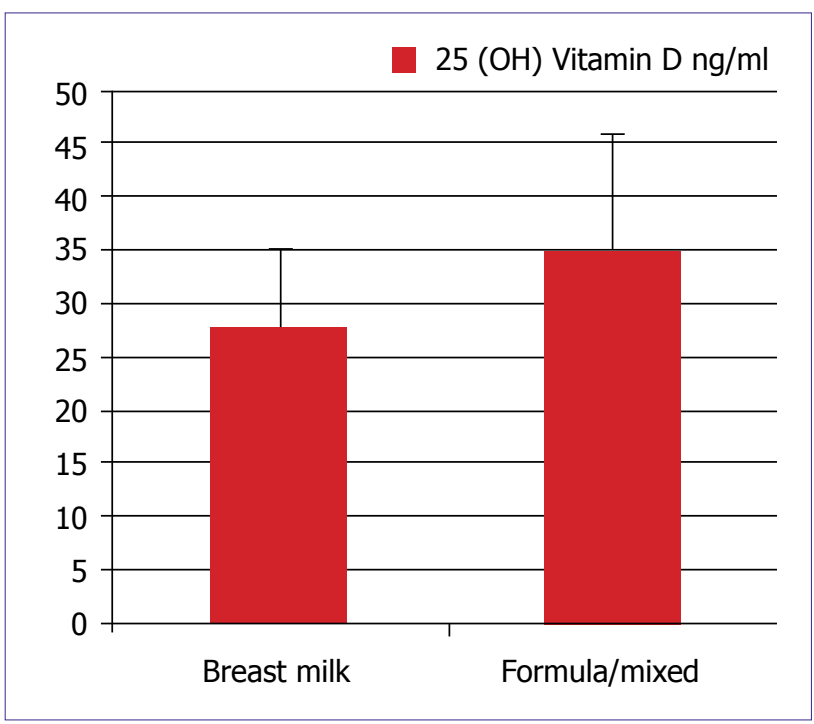

FIGURE 1. Dietary patterns of newborns and Vitamin D levels.
$\mathrm{mL})$. Only 6 of those (4\%) had vitamin D levels within normal limits ( $>32 \mathrm{ng} / \mathrm{mL}$ ). No statistically significant relationship was found between vitamin $D$ levels of mothers and presence of craniotabes at discharge or at 1 month of age. Analysis revealed that $95.3 \%$ of the newborns had $400 \mathrm{IU}$ of vitamin D supplementation. No statistically significant relationship was found between the incidence of craniotabes and vitamin D supplementation.

\section{DISCUSSION}

Vitamin D is a fat-soluble vitamin; however, it is produced in tissue and released into the bloodstream. It acts on other tissue with "feedback" mechanisms and is considered a steroid hormone rather than a vitamin $[12,13]$.

Craniotabes is detected in $30 \%$ of healthy newborns and usually disappears in 2-3 months [1,2]. A study in Japan suggested that physiological craniotabes frequency in newborn infants might be a result of in utero exposure to vitamin D deficiency [11]. Craniotabes was detected in $22 \%$ of neonates in that study, and $27 \%$ still had craniotabes at 1 month of age. In the present study, $30 \%$ of newborns had craniotabes, and $68.8 \%$ of those had persistent craniotabes at 1 month of age. Although no statistically significant relationship was found in terms of frequency of craniotabes among mothers who smoke cigarettes, $50 \%$ of smokers' infants had craniotabes whereas this was true for only $27.9 \%$ of non-smokers' infants. Recently, many studies conducted in various countries have found that $25(\mathrm{OH})$ vitamin $\mathrm{D}$ levels in mothers who give birth in the summer and autumn months were higher than in those who give birth in the winter and spring months [14-17]. In one study, $25(\mathrm{OH})$ vitamin D levels were found to be higher in patients diagnosed with nutritional rickets during summer months than those diagnosed during winter months [18]. In the present study, craniotabes was significantly higher in neonates born during the winter months. But no statistically significant difference was found in terms of $25(\mathrm{OH})$ vitamin $\mathrm{D}$ levels of neonates born in summer or winter months and their mothers.

Recent studies have also found that adminis- 
tration of $800-1600 \mathrm{IU} /$ day of vitamin D during pregnancy was insufficient for normal serum 25 OH vitamin D levels $[19,20]$. In a study with broad participation, $25(\mathrm{OH})$ vitamin $\mathrm{D}$ level was found to be higher in mothers given vitamin $\mathrm{D}$ supplementation during pregnancy and in their infants at sixth postnatal day [21]. In the present study, only 3 mothers (2\%) were given 1200 IU of vitamin D supplementation. Infants with and without craniotabes were evaluated according to their mothers' calcium and vitamin D supplement intake during pregnancy and duration of supplementation. There were no statistically significant differences between the two groups. In conclusion, despite a program launched in 2011 in Turkey, pregnant women still do not receive adequate vitamin $\mathrm{D}$ supplementation. All physicians dealing with the issue in the country have a big responsibility in this respect. Breast milk is poor in vitamin $\mathrm{D}$, containing about 10 to $60 \mathrm{U} / \mathrm{L}$ [22]. A study compared infants fed breast milk and fed vitamin D-fortified formula in addition to breast milk and found, similar to the present study, serum 25-OH vitamin D levels were higher in formula-fed [23] infants. There was no statistically significant difference between infants with or without craniotabes in terms of their feeding patterns and vitamin D supplementation status.

In the present study, vitamin D status in children was evaluated according to proposals of American Pediatric Endocrine Association [24]. In only $2.7 \%$ of newborns were $25(\mathrm{OH})$ vitamin D levels $<15 \mathrm{ng} / \mathrm{mL}$. All of those were breastfed and $50 \%$ did not have vitamin D supplementation. Vitamin D levels $(>20 \mathrm{ng} / \mathrm{mL}$ ) were adequate in $90 \%$ of the newborns. This indicates that a free vitamin D support program for newborns started in 2005 by the Ministry of Health in Turkey is being implemented effectively and that $400 \mathrm{IU}$ of vitamin D is sufficient for newborns [25]. In the present study, no statistically significant difference was observed between the two groups in terms of craniotabes detected at 1 month of age and serum Ca, P, ALP, $25(\mathrm{OH})$ vitamin $\mathrm{D}, \mathrm{PTH}$ levels and spot urine calcium/ creatinine levels. The vitamin $\mathrm{D}$ support program has also had a positive effect on incidence of rickets, which has decreased noticeably [18].
Recently, reports in different countries have been published about frequent vitamin $\mathrm{D}$ deficiency in women of childbearing age, pregnant and nursing mothers and significant risks of this situation for mothers and babies [26-28]. In studies conducted in Turkey, vitamin D levels of mothers are quite low, as were the levels in the present study $[15,29,30]$. The present analysis indicated median maternal vitamin $\mathrm{D}$ levels did not differ significantly between the two groups, but $6.6 \%$ of the mothers of infants with craniotabes had $25(\mathrm{OH})$ vitamin D levels $<10 \mathrm{ng} / \mathrm{mL}$; only $0.95 \%$ of mothers of infants without craniotabes had $25(\mathrm{OH})$ vitamin $\mathrm{D}$ level $<10$ $\mathrm{ng} / \mathrm{mL}(8.2 \mathrm{ng} / \mathrm{mL})$. Only 6 of the mothers had vitamin D levels in normal range $(>32 \mathrm{ng} / \mathrm{mL})$. This suggests that in Turkey, pregnant women do not get appropriate supplementation of vitamin D.

As a result of this study, although we cannot identify a clear relationship between neonatal craniotabes and maternal vitamin $\mathrm{D}$ deficiency, we suggest that more extensive studies be conducted focusing on the subject. Maternal vitamin D deficiency is still a major issue in Turkey. The authors suggest that at least 1600-2000 IU of vitamin D supplementation per day should be included in antenatal care for pregnant women.

Conflict of Interest: No conflict of interest was declared by the authors.

Financial Disclosure: The authors declared that this study has received no financial support.

Authorship contributions: Concept - M.E., M.K.; Design - M.E., M.K., M.Ö.; Supervision - G.Ö.; Funding - A.Y., G.Ö.; Materials - M.E., M.K., M.Ö.; Data collection and/or processing - M.E., M.K.; Analysis and/or interpretation - M.K., B.G.; Literature search - M.E., M.K.; Writing - M.K., M.E.; Critical review - B.G., A.Y.

\section{REFERENCES}

1. Fox GN, Maier MK. Neonatal craniotabes. Am Fam Physician 1984;30:149-51.

2. Otto FM, Hesse V. Craniotabes, craniomalacia (Wieland) and active ricketts in infants. [Article in German] Kinderarztl Prax 1990;58:179-83. [Abstract]

3. Vitamin D supplement in early childhood and risk for Type I (insulin-dependent) diabetes mellitus. The EURODIAB Substudy 2 Study Group. Diabetologia 1999;42:51-4. Crossref

4. Hyppönen E, Läärä E, Reunanen A, Järvelin MR, Virtanen SM. 
Intake of vitamin $\mathrm{D}$ and risk of type 1 diabetes: a birth-cohort study. Lancet 2001;358:1500-3. Crossref

5. Ward LM. Vitamin D deficiency in the 21st century: a persistent problem among Canadian infants and mothers. CMAJ 2005;172:769-70. Crossref

6. American Academy of Pediatrics. Clinical Report: Prevention of Rickets and Vitamin D Deficiency: New Guidelines for Vitamin D. Pediatrics 2003;111:908-11. Crossref

7. Pehlivan I, Hatun S, Aydoğan M, Babaoğlu K, Gökalp AS. Maternal vitamin $\mathrm{D}$ deficiency and vitamin $\mathrm{D}$ supplementation in healthy infants. Turk J Pediatr 2003;45:315-20.

8. Javaid MK, Crozier SR, Harvey NC, Gale CR, Dennison EM, Boucher BJ, et al. Maternal vitamin D status during pregnancy and childhood bone mass at age 9 years: a longitudinal study. Lancet 2006;367:36-43. Crossref

9. Camargo Jr CA, Rifas-Shiman SL, Litonjua AA, Edwards JWR, Weiss ST, Gold DR, et al. Prospective study of maternal intake of vitamin D during pregnancy and risk of wheezing illness in children at age 2 years. J Allergy Clin Immunol 2006;117(3):721-2.

10. Najada AS, Habashneh MS, Khader M. The frequency of nutritional rickets among hospitalized infants and its relation to respiratory diseases. J Trop Pediatr 2004;50:364-8. Crossref

11. Yorifuji J, Yorifuji T, Tachibana K, Nagai S, Kawai M, Momoi $\mathrm{T}$, et al. Craniotabes in normal newborns: the earliest sign of subclinical vitamin D deficiency. J Clin Endocrinol Metab 2008;93:1784-8. Crossref

12. Şimşek E, Kocabay K. Calcium, phosphorus and magnesium homeostasis. Türkiye Klinikleri J Pediatr 2002;11:211-20.

13. Güven A, Ecevit A, Tarcan A, Tarcan A, Özbek N. Cord blood vitamin D levels. Çocuk Sağ Hast Derg 2011;54:55-61.

14. Sachan A, Gupta R, Das V, Agarwal A, Awasthi PK, Bhatia $\mathrm{V}$. High prevalence of vitamin $\mathrm{D}$ deficiency among pregnant women and their newborns in northern India. Am J Clin Nutr 2005;81:1060-4.

15. Bodnar LM, Simhan HN, Powers RW, Frank MP, Cooperstein E, Roberts JM. High prevalence of vitamin D insufficiency in black and white pregnant women residing in the northern United States and their neonates. J Nutr 2007;137:447-52.

16. Hollis BW, Pittard WB 3rd. Evaluation of the total fetomaternal vitamin $\mathrm{D}$ relationships at term: evidence for racial differences. J Clin Endocrinol Metab 1984;59:652-7. Crossref

17. Nicolaidou P, Hatzistamatiou Z, Papadopoulou A, Kaleyias J, Floropoulou E, Lagona E, et al. Low vitamin D status in mother- newborn pairs in Greece. Calcif Tissue Int 2006;78:337-42.

18. Ozkan B, Doneray H, Karacan M, Vançelik S, Yildirim ZK, Ozkan $\mathrm{A}$, et al. Prevalence of vitamin $\mathrm{D}$ deficiency rickets in the eastern part of Turkey. Eur J Pediatr 2009;168:95-100. Crossref

19. Mulligan ML, Felton SK, Riek AE, Bernal-Mizrachi C. Implications of vitamin $\mathrm{D}$ deficiency in pregnancy and lactation. Am J Obstet Gynecol 2010;202:429.e1-9. Crossref

20. Holick MF, Binkley NC, Bischoff-Ferrari HA, Gordon CM, Hanley DA, Heaney RP, et al. Evaluation, treatment, and prevention of vitamin $\mathrm{D}$ deficiency: an Endocrine Society clinical practice guideline. J Clin Endocrinol Metab 2011;96:1911-30.

21. Cockburn F, Belton NR, Purvis RJ, Giles MM, Brown JK, Turner TL, et al. Maternal vitamin D intake and mineral metabolism in mothers and their newborn infants. Br Med J 1980;281:11-4.

22. Henderson A. Vitamin D and the breastfed infant. J Obstet Gynecol Neonatal Nurs 2005;34:367-72. Crossref

23. Greer FR. Vitamin D deficiency--it's more than rickets. J Pediatr 2003; 143:422-3. Crossref

24. Misra M, Pacaud D, Petryk A, Collett-Solberg PF, Kappy M; Drug and Therapeutics Committee of the Lawson Wilkins Pediatric Endocrine Society. Vitamin D deficiency in children and its management: review of current knowledge and recommendations. Pediatrics 2008;122:398-417. Crossref

25. Hatun S, Bereket A, Ozkan B, Coşkun T, Köse R, Calýkoğlu AS. Free vitamin D supplementation for every infant in Turkey. Arch Dis Child 2007;92:373-4. Crossref

26. Gannagé-Yared MH, Chemali R, Yaacoub N, Halaby G. Hypovitaminosis $\mathrm{D}$ in a sunny country: relation to lifestyle and bone markers. J Bone Miner Res 2000;15:1856-62. Crossref

27. Ghannam NN, Hammami MM, Bakheet SM, Khan BA. Bone mineral density of the spine and femur in healthy Saudi females: relation to vitamin D status, pregnancy, and lactation. Calcif Tissue Int 1999;65:23-8. Crossref

28. Mishal AA. Effects of different dress styles on vitamin D levels in healthy young Jordanian women. Osteoporos Int 2001;12:9315. Crossref

29. Andiran N, Yordam N, Ozön A. Risk factors for vitamin D deficiency in breast-fed newborns and their mothers. Nutrition. 2002;18:47-50. Crossref

30. Ergür AT, Berberoğlu M, Atasay B, Şıklar Z, Bilir P, Arsan S, et al. Vitamin D deficiency in Turkish mothers and their neonates and in women of reproductive age. J Clin Res Pediatr Endocrinol 2009;1:266-9. Crossref 